\title{
IMPLEMENTASI FATWA DEWAN SYARIAH NASIONAL NOMOR. 03/DSN-MUI/IV/2000 TENTANG DEPOSITO (STUDI PADA BANK MUAMALAT INDONESIA CABANG PALU)
}

\author{
Soimun Rohman ${ }^{1}$, Ermawati $^{2}$, Murniati Ruslan ${ }^{3}$ \\ ${ }^{1}$ Mahasiswa ${ }^{2,3}$ Dosen Institut Agama Islam Negeri Palu \\ soimunr@gmail.com
}

\begin{abstract}
Sharia banks in conducting business activities must be based on sharia principles. Based on the mandate of Law Number. 21 of 2008 concerning Islamic Banking and BI Regulation Number. 6/24 / PBI / 2004 that the DSN has the duty and authority to stipulate fatwas regarding products and services in the business activities of Banks which carry out business activities based on Sharia principles. To ensure that the deposit products at Bank Muamalat comply with the standards set by the DSN, a research was conducted at Bank Muamalat Indonesia, the Palu branch. Deposit products at the Palu branch of Bank Muamalat Indonesia use the Mudharabah Mutlaqah contract, where BMIs are given freedom in managing customer funds. Then it is reviewed on the rules of the DSN-MUI Fatwa Number. 03 / DSN-MUI / IV / 2000 based on the 6-point provision that must be implemented to achieve sharia principles. In its implementation, the mudharabah time deposit product run by Bank Muamalat Indonesia, Palu branch has met these provisions. so the product of mudharabah time deposits or deposits in the Palu branch of Bank Muamalat Indonesia is in accordance with the fatwa.
\end{abstract}

Keywords: DSN-MUI; Deposit; Muamalat Indonesia.

\begin{abstract}
Abstrak
Bank Syariah dalam melakukan kegiatan usaha harus berdasarkan prinsip syariah. Berdasarkan amanat Undang-undang Nomor. 21 Tahun 2008 tentang Perbankan Syariah dan Peraturan BI Nomor. 6/24/PBI/2004 bahwa DSN bertugas dan memiliki kewenangan untuk menetapkan fatwa tentang produk dan jasa dalam kegiatan usaha Bank yang melaksanakan kegiatan usaha berdasarkan berdasarkan prinsip Syariah. untuk memastikan produk deposito yang ada di Bank Muamalat sesuai standar yang ditetapkan oleh DSN, maka dilakukan penelitian di Bank Muamalat Indonesia cabang Palu. Produk deposito di Bank Muamalat Indonesia cabang Palu menggunakan akad Mudharabah Mutlaqah, dimana BMI diberi kebebasan dalam pengelolaan dana nasabah. Kemudian ditinjau pada aturan Fatwa DSN-MUI Nomor. 03/DSN-MUI/IV/2000 berdasarkan ketentuan 6 poin yang harus dilaksanakan untuk tercapainya prinsip syariah, Dalam implementasinya produk simpanan berjangka mudharabah yang dijalankan oleh Bank Muamalat Indonesia cabang Palu telah memenuhi ketentuan-ketentuan tersebut. jadi produk simpanan berjangka mudharabah atau deposito yang ada di Bank Muamalat Indonesia cabang Palu telah sesuai dengan fatwa tersebut.
\end{abstract}

Kata kunci: Deposito; Fatwa DSN-MUI; Muamalat Indonesia.

TADAYUN:

Jurnal Hukum Ekonomi Syariah

Vol.1 No.2, Juli-Desember 2020 | 181

E-ISSN: 2774-4914 


\section{A. PENDAHULUAN}

Bank merupakan lembaga keuangan penghimpun dana masyarakat berbentuk simpanan serta menyalurkannya pada masyarakat dengan bentuk kredit ataupun bentuk lainnya. ${ }^{1}$ Di Indonesia Bank terbagi menjadi dua jenis yang dikenal dikalangan masyarakat yaitu Bank Konvensional dan Bank Umum Syariah. Bank Konvensional yaitu Bank yang menjalakan sistemnya dengan cara perhitungan bunga, sementara Bank Syariah melaksanakan operasionalnya berdasar akan prinsip syariah. Diantara banyaknya Bank Syariah yang ada di Indonesia Bank Muamalat Indonesia atau yang biasa disebut dengan BMI merupakan Bank yang di klaim menerapkan sistem syariah murni, selain itu juga Bank Muamalat menjadi contoh bagi Bank-Bank Syariah yang ada di Indonesia dengan menggunakan sistem syariah.

Bank Muamalat Indonesia tidak terlepas dari fungsinya sebagai Bank pada umumnya yaitu menyalurkan dan menghimpun dana, adapun produk penghimpunan ditawarkan antara lain tabungan, giro, dan deposito. Seiring dengan berkembangnya waktu produk deposito paling di minati oleh masyarakat Indonesia sehingga deposito mengalami peningkatan tiap tahunnya. Deposito memiliki daya tarik tersendiri dari masyarakat untuk lebih memilih melakukan simpanan deposito ataupun melakukan investasi dengan jangka yang pendek yakni 1, 3, 6 dan 12 bulan, apalagi persentase pengembalian pertahunnya yang dapat diperoleh nasabah dari melakukan simpanan deposito cukup tinggi dibandingkan persentase yang diperoleh dari tabungan biasa ataupun dari persentase giro. Tingkat risikonya pun terbilang sangat minim. Selain itu juga produk deposito pada Bank Muamalat menggunakan sistem syariah yeng menggunakan akad mudharabah.

Di dalam Undang-Undang Nomor. 21 Tahun 2008 tentang perbankan syariah pasal 19 dan 24 dijelaskan bahwa

Bank Syariah dalam melakukan kegiatan usaha menghimpun dana dalam bentuk investasi berupa deposito. Deposito harus berdasarkan akad mudharabah. Dan apabila Bank Syariah dalam melakukan kegiatan usaha bertentangan dengan prinsip syariah maka akan dikenakan sanksi

${ }^{1}$ Gatot Supramono, Perbankan dan Masalah Kredit Suatu Tinjauan di Bidang Yuridis, (Jakarta : Rineka Cipta, 2009), 45. 
administratif sebagai mana pasal 16 dalam Undang-Undang perbankan syariah.

Prinsip syariah yang dimaksud sebagaimana pasal 26 di fatwakan oleh Majelis Ulama Indonesia dan Dewan Syariah Nasional pada fatwa Nomor 03/DSN-MUI/IV/2000 tentang deposito. Berdasarkan amanat Undang-undang Nomor 21 Tahun 2008 tentang Perbankan Syariah pasal 1 poin 12 dan Peraturan Bank Indonesia Nomor. 6/24/PBI/2004 pasal 1 poin 12, bahwa

Dewan Syariah Nasional bertugas dan memiliki kewenangan untuk menetapkan fatwa tentang produk dan jasa dalam kegiatan usaha Bank yang melaksanakan kegiatan usaha berdasarkan prinsip syariah. ${ }^{2}$

Dengan adanya peraturan tentang deposito dengan menggunakan prinsip syariah, artinya fatwa Nomor 03/DSN-MUI/IV/2000 tentang deposito menjadi aturan rujukan bagi seluruh Bank Umum Syariah sehingga menjadi sebuah kewajiban bagi setiap Bank Syariah untuk mengikuti ketentuan-ketentuan yang telah ada dalam aturan tersebut, demi terjaga ke syariahan dari produk-produk yang ada pada Bank Umum Syariah terutama pada Bank Muamalat Indonesia. Dalam tulisan ini penulis akan membahas terkait hasil penelitian pada Bank Muamalat Indonesia cabang Palu yang dilakukan untuk memastikan produk deposito yang ada di Bank Muamalat sesuai standar yang ditetapkan oleh Dewan Syariah Nasional.

\section{B. PEMBAHASAN}

\section{Deposito Syariah}

Bank Syariah dari sisi penghimpunan dana sumbernya terdiri dari modal, investasi serta titipan. Deposito yang dimiliki Bank Syariah merupakan sumber ivestasi masyarakat yang terhimpun melalui akad mudharabah. ${ }^{3}$ Deposito merupakan tabungan investasi melalui simpanan pihak ketiga yang dalam hal ini adalah Bank. penarikannya hanya dapat dilakukan sesuai jangka waktu yang telah disepakati di awal akad. Kemudian Bank akan memberikan keuntungan dengan sistem bagi hasil, semisal 70\% :

\footnotetext{
${ }^{2}$ Abdul Ghofur Anshori, Payung Hukum Perbankan Syariah (UU di Bidang Perbankan, Fatwa DSN-MUI, dan Peraturan Bank Indonesia), (Yogyakarta : UII Press, 2009), 229 2000), 146.

${ }^{3}$ Muhammad Syafi'I Antonio, Bank Syari'ah dari Teorike Praktik, (Cet. I ; Jakarta : Gema Insani Press,
} 
$30 \%$, yang berarti keuntungan yang diperoleh oleh Bank akan dibagi berdasarkan presentasi tersebut.

Selanjutnya, sesuai ketentuan yang ditetapkan oleh Dewan Syariah Nasional melalui fatwa DSN-MUI menetapkan deposito yang dibolehkan untuk dipraktikkan pada lembaga keuangan adalah deposito yang berdasar akan prinsip mudharabah. ${ }^{4}$

Mudharabah ialah kerjasama antara seorang partner yang memberikan uang kepada partner lain untuk di investasikan ke perusahaan komersial. Pihak Bank (shahibul maal) berkewajiban memberikan dana 100\% kepada nasabah (mudharib) dan mudharib hanya mengelola usaha yang sudah ditentukan oleh pihak shahibul maal. Pembagian keuntungan akan dibagi berdasarkan kesepakatan pada awal kontrak, sedangkan jika terjadi kerugian akan ditanggung oleh pemilik modal. Pengelola juga bertanggung jawab apabila kerugian itu disebabkan oleh pihak pengelola. ${ }^{5}$

Terlepas dari pengertian di atas mudharabah adalah akad kerja sama usaha antara dua pihak, pihak pertama sebagai pemilik saham menyediakan seluruh sahamnya, sedangkan pihal kedua sebagai pengelola. Keuntungan usaha bersama dibagi sesuai dengan kepakatan yang dituangkan dalam kontrak, sedangkan apabila rugi ditanggung oleh pemilik saham selama kerugian tersebut bukan sebagai akibat kelalaian pihak pengelola. ${ }^{6}$

Terlaksananya akad mudharabah harus berdasarkan rukun berikut:

a) Dua Pihak, pihak yang berperan sebagai pemberi dana (shahib al-mal), dan pihak kedua yang berperan sebagai pengelola (mudharib atau amil);

b) Objek mudharabah (modal dan kerja), Shahib al-mal menyerahkan dana yang kemudian akan dikelola oleh mudharib dengan kerjanya;

c) Persetujuan kedua belah pihak (ijab-qabul), yakni persetujuan kedua belah pihak, merupakan konsekuensi dari prinsip an-taraddin minkum (sama-sama

${ }^{4}$ Fatwa Dewan Syariah Nasional Nomor 03/DSN-MUI/IV/2000 tentang Deposito.

${ }^{5}$ Russely Inti Dwi Permata “Jurnal Administrasi”, Analisis Pengaruh Pembiayaan Mudharabah dan Musyarakah Terhadap Tingkat Profitabilitas (Return On Equity) (Studi Pada Bank Umum Syariah yang Terdaftar di Bank Indonesia Periode 2009-2012), vol. 12 no. $1 \quad$ (2014), 3. http://administrasibisnis.studentjournal.ub.ac.id/index.php/jab/article/view/486 Niakses 31 Desember 2018).

${ }^{6} \mathrm{Abu}$ Azam Al Hadi, Fikih Muamalah Kontemporer, (Jakarta : PT RajaGrafindo Persada, 2017), 2. 
rela). Disini kedua pihak harus secara rela bersepakat untuk mengikatkan diri dalam akad mudharabah.

d) Nisbah keuntungan, Nisbah ini mencerminkan imbalan yang berhak diterima oleh kedua pihak yang bermudharabah. ${ }^{7}$

Mudharabah pada umumnya terdapat dua bentuk, yakni mudharabah mutlaqah dan mudharabah muqayyadah. Perbedaan utamanya adalah terletak pada ada atau tidaknya persyaratan yang diberikan pemilik dana kepada Bank untuk mengelola hartanya, baik dari sisi tempat, waktu, maupun objek investasinya. ${ }^{8}$

Pada unrestricted mudharabah/ mudharabah muthlaqah Bank wajib memberitahukan kepada pemilik dana mengenai nisbah dan rata cara pemberian keuntungan dan atau perhitungan pembagian keuntungan serta resiko yang dapat timbul, tabungan mudharabah dapat diambil setiap saat oleh penabung sesuai dengan perjanjian yang disepakati namun tidak boleh mengalami saldo negative, dan ketentuan-ketentuan lain berlaku selama tidak bertentangan dengan prinsip syariah. ${ }^{9}$ Pada jenis mudharabah muqayyadah atau disebut juga dengan istilah restricted mudharabah/specified mudharabah adalah kebalikan dari mudharabah muthlaqah. Si mudharib dibatasi dengan batasan jenis usaha, waktu, atau tempat usaha. Adanya pembatasan ini sering kali mencerminkan kecenderungan umum si shahib al-mal dalam memasuki jenis dunia usaha. ${ }^{10}$

Berdasarkan Fatwa Dewan Syariah Nasional No: 03/DSN-MUI/IV/2000 tentang Deposito yang ditetapkan di Jakarta tanggal 1 April $2000 \mathrm{M}$ bertepatan dengan 26 Dzulhijjah 1420 H. Oleh ketua Dewan Syariah Nasional (DSN) Majelis Ulama Indonesia (MUI) Prof. KH. Ali Yafie menetapkan bahwa deposito yang dibolehkan berdasarkan keputusan DSN MUI memiliki 6 poin yaitu : 2011), 205.

${ }^{7}$ Adiwarman A. Karim, Bank Islam Analisis Fiqih dan Keuangan, (Jakarta : PT RajaGrafindo Persada,

${ }^{8}$ Syaakir Sofyan, "Jurnal Bilancia : Jurnal Studi Ilmu Syariah dan Hukum", Perkembangan Perbankan Syariah di Indonesia, vol. 10 no. 2 (2016), 99. https://doi.org/10.24239/blc.v10i2.291 (Diakses 2 Januari 2019).

${ }^{9}$ Muhammad Fatibut T, “Jurnal Pendidikan Ekonomi”, Pengaruh dan Manfaat Bagi Hasil Terhadap Jumlah Simpanan Deposito Mudharabah Bank Syariah Mandiri di Indonesia, vol. 1 no. 3 (2013), http://jurnalmahasiswa.unesa.ac.id/index/php/jupe/article/view/3585 (Diakses 2 Januari 2019).

${ }^{10}$ Mardani, Fiqh Ekonomi Syariah: Fiqh Muamalah, (Jakarta : Kencana, 2012), 200. 
a) Dalam transaksi ini nasabah bertindak sebagai shahibul maal atau pemilik dana, dan Bank bertindak sebagai mudharib atau pengelola dana.

b) Dalam kapasitasnya sebagai mudharib, bank dapat melakukan berbagai macam usaha yang tidak bertentangan dengan prinsip syariah dan mengembangkannya, termasuk didalamnya mudharabah dengan pihak lain.

c) Modal harus dinyatakan dengan jumlahnya, dalam bentuk tunai bukan piutang.

d) Pembagian keuntungan harus dinyatakan dalam bentuk nisbah dan dituangkan dalam akad pembukaan rekening.

e) Bank sebagai mudharib menutup biaya operasional deposito dengan menggunakan nisbah keuntungan yang menjadi haknya.

f) Bank tidak diperkenankan untuk mengurangi nisbah keuntungan nasabah tanpa persetujuan yang bersangkutan. ${ }^{11}$

\section{Produk Deposito Pada Bank Muamalat Indonesia Cabang Palu}

Bank Muamalat Indonesia Cabang Palu yang biasa disebut BMI Cabang Palu ialah lembaga intermediary, yaitu penghubung antara pengelola dana dan pemilik dana. Salah satu kegiatan BMI Cabang Palu sebagai intermediary ialah penghimpun dana yang terkumpul dari nasabah kedalam bentuk simpanan Deposito iB Hijrah. Deposito iB Hijrah mrupakan investasi yang optimal bagi Nasabah. Deposito Mudharabah diperuntukan bagi Nasabah perorangan dan institusi yang memiliki legalitas badan hukum.

BMI Cabang Palu mempunyai usaha pokok berupa penghimpun dana. Dana yang dihimpun oleh Bank sebagian besar disalurkan dalam bentuk pembiayaan, baik untuk usaha produktif maupun untuk keperluan konsumtif. Deposito menurut Yoyo Sukaryatmo selaku Branch Sales Suport Bank Muamlat Indonesia Cabang Palu menjelaskan bahwa :

Deposito adalah dana nasabah yang disimpan di Bank dengan jumlah tertentu dan dalam jangka waktu yang tertentu pula, juga mendapat bagi hasil yang lebih tinggi. Jumlah dan jangka waktu deposito telah disepakati bersama oleh Bank

\footnotetext{
${ }^{11}$ Abdul Ghofur Nashori, Payung Hukum Perbankan Syariah (UU di Bidang Perbankan, Fatwa DSN-MUI, dan Peraturan Bank Indonesia, 121
} 
dan nasabah. Deposito menggunakan akad Mudharabah Muthlaqah yang memberikan kebebasan pada Bank selaku pengelola dana untuk memproduktifkan dana nasabah, yang meliputi jenis usaha dan jangka waktu. ${ }^{12}$

Pendapat diatas sejalan dengan pendapat Ascarya dalam buku "Akad \& Produk Bank Syariah" yang menjelaskan bahwa:

Dalam deposito mudharabah mutlaqah, bank sebagai mudharib mempunyai kebebasan mutlak dalam pengelolaan investasinya. Jangka waktu investasi dan bagi hasil disepakati bersama. Apabila bank menghasilkan keuntungan akan dibagi sesuai kesepakatan awal. Apabila bank mengalami kerugian, bukan karena kelalaian bank, kerugian ditanggung oleh nasabah deposan sebagai shahibul mal. ${ }^{13}$

Jadi, deposito yang ada pada BMI Cabang Palu merupakan simpanan berjangka yang menggunakan akad mudharabah muthlaqah, dimana nasabah memberikan kebebasan kepada Bank untuk mengelola dananya dengan jangka waktu dan pembagian porsi bagi hasil yang telah disepakati bersama. Terlepas dari itu, sebelum membuka tabungan deposito iB Hijrah nasabah diharuskan untuk melengkapi administrasi-administrasi yang ada pada BMI Cabang Palu, agar perjanjian antara nasabah dan pihak BMI Cabang Palu mempunyai kekuatan hukum tetap dan menghindari unsur cacat administrasi.

Adapun persyaratan administrasi yang harus dilengkapi menurut Muhlis selaku Costumer Service (CS) Bank Muamalat Indonesia Cabang Palu adalah :

Khusus perorangan ketika ingin membuka tabungan deposito persyaratan administrasi yang harus dilengkapi berupa, fotokopi Kartu Tanda Penduduk (KTP), Nomor Pokok Wajib Pajak (NPWP) jika ada. Sedangkan untuk NonPerorangan yang berupa, akta pendirian usaha, izin usaha yaitu TDP dan SIUP bagi badan usaha, surat kuasa penunjukan pengelolaan rekening, dan bukti identitas penerima dan pemberi kuasa. Untuk setoran awal baik perorangan dan Non-Perorangan minimal Rp 5.000 .000 (lima juta rupiah). ${ }^{14}$

\footnotetext{
8 April 2019

${ }^{12}$ Yoyo Sukaryatmo, Branch Sales Suport Bank Muamalat Indonesia Cabang Palu. Wawancara, Palu,

${ }^{13}$ Ascarya, Akad dan Produk Bank Syariah, (Jakarta: RajaGrafindo Persada, 2008)

${ }^{14}$ Muhlis, Costumer Service (CS) Bank Muamalat Indonesia Cabang Palu, Wawancara, 17 Juni 2019
} 
Dalam hal pelaksanaan prosedur Bank Muamalat Indonesia Cabang Palu dalam membuka tabungan iB Hijrah deposito, menurut Jumadi selaku RM Funding Reguler yaitu terdapat pada gambar berikut: ${ }^{15}$

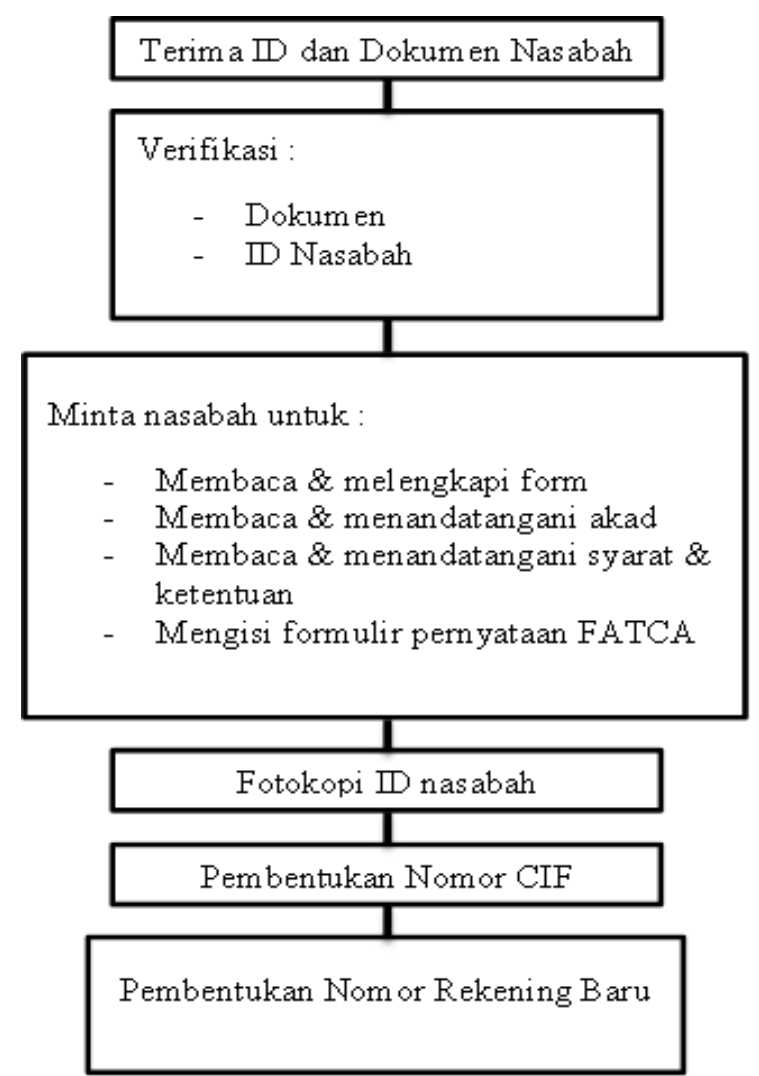

Gambar 1:

Prosedur Pelaksanaan Operasi Bank Muamalat Indonesia Cabang Palu

Gambar tersebut menjelaskan tentang prosedur pembukaan tabungan deposito hal ini sejalan dengan hasil observasi yang dilakukan oleh penulis pada Bank Muamalat Indonesia Cabang Palu, dimana nasabah akan diarahkan langsung oleh petugas untuk membuka tabungan deposito di bagian costumer service, kemudian nasabah akan diberikan sebuah formulir pembukaan rekening untuk diisi. Setelah semua data administrasi telah lengkap maka costumer service akan meminta setoran dengan minimal Rp5.000.000 dan setelah diproses nasabah akan menerima Advis deposito atau aplikasi deposito mudharabah. Setelah itu nasabah tinggal menunggu pengembalian modal serta keuntungan yang telah disepakati sejak awal akad.

\footnotetext{
${ }^{15}$ Jumadi, RM Funding Reguler Bank Muamalat Indonesia Cabang Palu, Wawancara, 17 April 2019
} 
Mekanisme tabungan berjangka atau deposito mudharabah pada Bank Muamalat Indonesia Cabang Palu Menurut Bambang Nugroho selaku pimpinan Bank Muamalat atau Branch Manajer BMI Cabang Palu menjelaskan bahwa:

Mekanisme tabungan berjangka atau deposito pada BMI Cabang Palu, telah melakukan sesuai dengan prinsip mudharabah. Dimana Bank sebagai mudharib akan mengelola dana yang akan diberikan oleh nasabah yang dalam hal ini adalah shahibul maal. Terlepas dari itu BMI Cabang Palu mempunyai kewajiban terkait transparansi informasi mengenai produk yang ada pada Bank, hak dan kewajiban nasabah serta penggunaan data pribadi nasabah. ${ }^{16}$

Terkait keuntungan nasabah akan mendapatkan keuntungan yang sifatnya fluktuatif dimana keuntungan tidak selalu sama dengan keuntungan sebelumnya. Maka dari itu, nasabah hanya diberikan pilihan terkait presentasi keuntungan atau nisbah bagi hasil saja. Pilihan jangka waktu yang diberikan oleh pihak BMI Cabang Palu bervariasi yaitu mulai dari jangka waktu 1, 3, 4, 6, dan 12 bulan. ${ }^{17}$

Kemudian terkait biaya-biaya yang akan dibebankan oleh nasabah yaitu berupa Pajak Penghasilan (Pph) dimana perjanjian ini telah dituangkan dalam akad perjanjian deposito pada saat pembukaan tabungan deposito, terlepas dari itu ada biaya yang sifatnya diwajibkan apabila nasabah melakukan penutupan deposito sebelum jatuh tempo hal ini dilakukan karena nasabah memutus kerja sama sebelum waktunya, biaya tersebut sebesar Rp30.000 sampai Rp50.000 tergantung dari jangka waktu nasabah menarik dananya. Dan yang terakhir ada pembebanan biaya yang sifatnya tidak memaksa yaitu dana Zakat, Infaq, Sedekah (ZIS). Dana tersebut harus meminta persetujuan dari nasabah terlebih dahulu, apabila nasabah membolehkan maka pihak BMI Cabang Palu akan memotong/menguranginya dari keuntungan nisbah yang didapatkan oleh nasabah. ${ }^{18}$

\footnotetext{
${ }^{16}$ Bambang Nugroho, Branch Manajer Bank Muamalat Indonesia Cabang Palu, Wawancara, 31 April 2019

${ }^{17}$ Ibid.,

${ }^{18}$ Ibid.,
} 


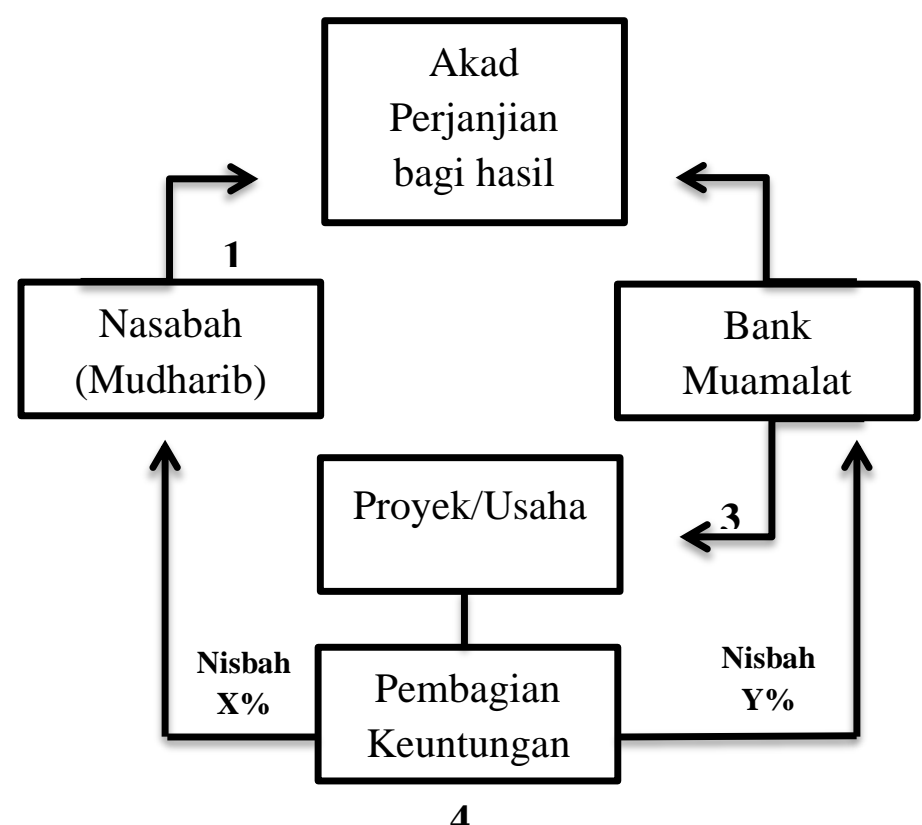

Gambar 2

Skema Akad Mudharabah Pada Bank Muamalat Indonesia

Penjelasan gambar diatas sejalan dengan hasil wawancara yang dilakukan oleh penulis terhadap yang dinyatakan oleh Branch Manajer Bank Muamalat Cabang Palu akad mudharabah adalah akad kerjasama, dimana nasabah selaku pemilik dana akan melakukan suatu perjanjian nisbah bagi hasil dengan pihak BMI Cabang Palu. setelah tercapainya suatu perjanjian maka pihak BMI Cabang Palu akan mengelola dana yang telah diberikan oleh nasabah. Dana tersebut akan dikelola dalam bentuk proyek atau usaha sesuai ketentuan BMI Cabang Palu. Kemudian setelah jatuh tempo BMI cabang Palu akan membagikan hasil keuntungan yang diperoleh kepada nasabah sesuai perjanjian yang telah disepakati sejak pertama melakukan akad.

\section{Produk Deposito Dalam Tinjauan Fatwa Dewan Syariah Nasional Nomor 03/DSN-MUI/IV/2000 Tentang Deposito}

Berdasarkan Fatwa DSN Nomor 03/DSN-MUI/IV/2000 berkaitan deposito, menetapkan yang tidak dibolehkan secara Syariah ialah deposito yang menggunakan perhitungan bunga serta deposito yang dibolehkan ialah yang berlandaskan akan prinsip mudharabah. Sedangkan untuk merealisasikan di dunia perbankan maka Bank wajib mengikuti semua ketentuan-ketentuan yang ada pada fatwa DSN tersebut. adapun analisis yang penulis lakukan mengenai ketentuan-ketentuan deposito yaitu: 
a. Dalam transaksi ini nasabah bertindak sebagai shahibul maal atau pemilik dana, dan bank bertindak sebagai mudharib atau pengelola dana.

Sebagai pelaku pengelola dana yang dalam hal ini Bank Muamalat Indonesia Cabang Palu. Kemudian nasabah selaku pemilik dana akan menyimpan dana mereka dalam bentuk tabungan deposito.

Terkait dengan ketentuan tersebut dan berdasarkan hasil wawancara yang dilakukan oleh penulis mengenai hal tersebut dijelaskan oleh Bambang Nugroho selaku Branch Manajer Bank Muamalat Indonesia Cabang Palu. Ia menegaskan bahwa dalam praktiknya Bank bertindak sebagai pengelola dana sedangkan nasabah bertindak sebagai pemilik modal yang memberikan kepercayaan terhadap Bank Muamalat Cabang Palu untuk mengelola dana nasabah. Hal ini telah sejalan dengan ketentuan poin pertama yang ada pada Fatwa Dewan Syariah Nasional tentang Deposito sehingga Bank Muamalat Cabang Palu telah memenuhi prosedurnya.

b. Dalam kapasitasnya sebagai mudharib, bank dapat melakukan berbagai macam usaha yang tidak bertentangan dengan prinsip syariah dan mengembangkannya, termasuk didalamnya mudharabah dengan pihak lain.

Dalam hal pengelolaan jenis usaha, Bank Muamalat Cabang Palu diwajibkan mengembangkan dana yang diperoleh dari nasabah tidak bertentangan dengan prinsip syariah, termasuk bekerjasama dengan pihak lain. Hal ini sejalan dengan hasil wawancara penulis dengan Yoyo Sukaryatmo selaku Branch Sales Suport dia menjelaskan bahwa Deposito pada Bank Muamalat Cabang Palu berdasar akan akad Mudharabah Muthlaqah yangmana pihak Bank diberikan keleluasaan untuk mengelola dana agar dana dapat terus produktif. Menurut Bambang Nugroho selaku Branch Manajer dalam pengalokasian dana tersebut terbagi menjadi 2 kategori yaitu Individu dan NonIndividu. Adapun kategori pertama yaitu individu dimana pengalokasian dana ini akan disalurkan ke masyarakat biasa seperti pedagang dan usaha-usaha mikro lainnya, sedangkan untuk kategori kedua yaitu Non-Individu dimana pengalokasian dana ini akan disalurkan ke lembaga-lembaga yang berbadan hukum seperti, sekolah atau kampus, pemerintahan dan perusahan-perusahaan lainnya. Dalam hal ini Bank Muamalat Indonesia Cabang Palu telah sejalan dengan poin nomor dua tersebut. 
c. Modal harus dinyatakan dengan jumlahnya, dalam bentuk tunai dan bukan piutang.

Pada poin 3 dalam ketentuan Fatwa DSN terkait deposito ialah nasabah harus menyertakan modal pada saat pembukaan tabungan deposito secara tunai dan berdasarkan hasil wawancara dan observasi yang telah dilakukan penulis di Bank Muamalat Cabang Palu. menurut Jumadi selaku RM Funding Reguler BMI Cabang Palu menjelaskan bahwa ketika ingin membuka tabungan iB Hijrah Deposito maka hal pertama yang harus dilakukan adalah menyiapkan persyaratan yang telah ditetapkan oleh pihak BMI Cabang Palu, seperti fotokopi identitas diri dan setoran awal minimal Rp5.000.000 (Lima Juta Rupiah). Sedangkan dalam praktinya dilapangan melalui observasi yang penulis lakukan telah sejalan dengan penjelasan Jumadi tersebut. Dimana nasabah ketika ingin membuka tabungan deposito akan diarahkan langsung oleh petugas BMI Cabang Palu untuk pergi ke Costumer Service kemudian nasabah akan diberikan sebuah formulir pembukaan rekening untuk diisi. Setelah semua data administrasi telah lengkap maka costumer service akan meminta setoran dengan minimal Rp5.000.000. hal ini menunjukan bahwa dana yang diserahkan oleh nasabah bukan dalam bentuk piutang melainkan tunai. Maka Bank Muamalat Cabang Palu telah sesuai dengan pin nomor tiga mengenai ketentuan deposito yang dikeluarkan oleh Fatwa Dewan Syariah.

d. Pembagian keuntungan harus dinyatakan dalam bentuk nisbah serta dicantumkan dalam akad pembukaan rekening.

Dalam melaksanakan kegiatan usaha dibidang deposito pada Bank Muamalat Indonesia Cabang Palu. berdasarkan hasil wawancara bersama Branh Sales Suport Yoyo Sukaryatmo, secara prosedur, nasabah pada awalnya akan diberikan penjelasan terkait produk deposito dan keuntungan dari deposito pada Bank Muamalat Indonesia Cabang Paluitu sendiri. Adapun produk deposito pada BMI Cabang Palu terdiri dari 2 macam sistem deposito yakni sistem ARO (Automatic Roll Over) dan sistem deposito Non-ARO. Sistem deposito ARO artinya perpanjangan otomatis tabungan deposito tanpa pemberitahuan kepada nasabah lagi, sedangkan sistem Non-ARO adalah kebalikan dari siste ARO dimana Non-ARO akan berhenti sesuai tempo yang telah ditentukan sejak awal akad. 
Terlepas dari itu, terkait keuntungan dari deposito pada Bank Muamalat Indonesia Cabang Palu, tidak didasarkan pada sistem bunga/presentase nilai uang yang telah di depositokan. Akan tetapi keuntungan didasarkan pada prinsip syariah yakni system pembagian hasil keuntungan (Nisbah). Pembagian hasil keuntungan (Nisbah) yang dimaksud Bank Muamalat Indonesia Cabang Palu selaku mudharib akan mengelola uang nasabah yang telah di depositokan pada dan dari hasil keuntungan pengelolaan tersebut akan dibagi dua, yakni keuntungan untuk pihak BMI Cabang Palu dan keuntungan untuk pihak nasabah itu sendiri. Adapun pembagian hasil keuntungan dari pengelolaan pada BMI Cabang Palu tersebut sebagai berikut:

\begin{tabular}{|c|c|}
\hline Jangka Waktu & Nisbah \\
\hline 1 Bulan & (Nasabah : Bank) $50 \%: 50 \%$ \\
\hline 3 Bulan & (Nasabah : Bank) $51 \%: 49 \%$ \\
\hline 4 Bulan & (Nasabah : Bank) $52 \%: 48 \%$ \\
\hline 6 Bulan & (Nasabah: Bank) $54 \%: 47 \%$ \\
\hline 12 Bulan & (Nasabah : Bank) $54 \%: 46 \%$ \\
\hline
\end{tabular}

Tabel 1

Jangka Waktu dan Pembagian Nisbah Antara Nasabah dan Bank Pada Bank Muamalat Cabang Palu ${ }^{19}$

Bahwa secara prosedur pembagian hasil keuntungan (Nisbah) di BMI Cabang Palu dilakukan dan dituangkan didalam akad pembukaan rekening deposito. Sebagaimana dalam Fatwa DSN Nomor 3 pada poin 4 disebutkan: "Pembagian keuntungan harus dinyatakan dalam bentuk nisbah dan dituangkan dalam akad pembukaan rekening" Sebagaimana Fatwa DSN tersebut. BMI Cabang Palu secara praktiknya tentunya sudah melaksanakan ketentuan tersebut. Dimana Bank sebagai mudharib memberikan keuntungan dalam bentuk nisbah dan dituangkan dalam akad pembukaan rekening sehingga tentunya hal ini telah sejalan dengan prinsip syariah atau prinsip mudharabah.

Hal ini juga dijelaskan oleh salah satu nasabah Bank Muamalat Cabang Palu, berdasarkan pengelamannya ketika membuka rekening deposito ia diberikan pilihan jangka waktu lengkap dengan pembagian presentase nisbahnya. Kemudain Costumer Service menjelaskan kepada nasabah bahwa Nisbah tersebut bukan hasil keuntungan

${ }^{19}$ Bambang Nugroho, Branch Manajer Bank Muamalat Cabang Palu, Wawancara, 31 April 2019 
melainkan persentase bagi hasil antara pihak bank dan nasabah. Jadi, keuntungan tidak selalu sama dengan keuntungan sebelumnya.

e. Bank sebagai mudharib menutup biaya operasional deposito dengan menggunakan nisbah keuntungan yang menjadi haknya.

Biaya operasional untuk produk deposito pada Bank Muamalat Cabang Palu berdasarkan hasil observasi dan wawancara bersama Yoyo Sukaryatmo untuk pembukaan rekening deposito tidak dikenakan biaya administrasi dan untuk biaya penutupan pun tidak terdapat biaya administrasi. Akan tetapi ketika nasabah melakukan wanprestasi dalam hal ini nasabah memutus kerjasama deposito diluar waktu yang telah ditentukan didalam akad, maka konsekuensinya nasabah akan dikenai biaya Break (biaya penutupan deposito sebelum jatuh tempo) hal ini juga merupakan bentuk sanksi wanprestasi yang dilakukan nasabah terhadap akad dengan pihak Bank Muamalat Indonesia Cabang Palu. sanksi biaya Break tersebut yakni Rp30.000 sampai Rp50.000 yang dibebankan kepada nasabah dan tergantung dari jangka waktunya.

Bahwa sebagaimana Fatwa DSN Nomor 3 poin 5 disebutkan bahwa : "Bank sebagai mudharib menutup biaya operasional deposito dengan menggunakan nisbah keuntungan yang menjadi haknya" Artinya Bank sebagai mudharib tidak dibenarkan memungut biaya apapun dalam hal penutupan deposito sehingga jika dikaitkan praktik deposito pada Bank Muamalat Indonesia Cabang Palu sudah melaksanakan ketentuan poin 5 Fatwa DSN tersebut dan tentunya telah sesuai dengan prinsip syariah dan prinsip mudharabah.

f. Pihak Bank Syariah tidak diperkenankan untuk mengurangi nisbah keuntungan nasabah tanpa persetujuan yang bersangkutan.

Larangan pengurang keuntungan tanpa persetujuan nasabah, terkait dengan larangan pengurangan keuntungan, BMI Cabang Palu telah melakukan praktiknya sesuai dengan ketentuan Fatwa DSN Nomor 3 poin 6 tersebut. Hal ini telah ditegaskan oleh Branch Manajer BMI Cabang Palu, Bambang Nugroho mengatakan bahwa BMI Cabang Palu mengikuti aturan yang dikeluarkan oleh Bank Indonesia Nomor 7/46/PBI/2005 Tentang akad penghimpun serta penyaluran dana pada bank yang beroperasi secara syariah. Sehingga BMI Cabang Palu tidak melakukan pengurangan 
terhadap nisbah keuntungan yang didapatkan oleh nasabah tanpa persetujuan yang bersangkutan. Dan dengan persetujuan nasabah, bank dapat memotong bagi hasil deposito yang diterima nasabah untuk pembayaran zakat, infaq, sedekah (ZIS) sebesar $2,5 \%$.

Hal ini juga diperkuat oleh salah satu nasabah Bank Muamalat Indonesia Cabang Palu yang menyatakan bahwa tidak ada penarikan atau pengurangan nisbah tanpa persetujuan pemilik tabungan deposito kecuali pembebanan pajak penghasilan (Pph) kepada nasabah yang telah ada dalam akad perjanjian. Karena pada dasarnya bank telah diberi kuasa oleh nasabah untuk melakukan pemotongan pajak penghasilan atas pendapatan bagi hasil deposito yang diterima nasabah sesuai ketentuan hukum yang berlaku.

Sebagaimana Fatwa DSN tersebut. BMI Cabang Palu secara praktiknya tentunya sudah melaksanakan ketentuan tersebut. Karena pada dasarnya bank tidak dibenarkan mengurangi nisbah keuntungan milik nasabah sebelum ada persetujuan dari nasabah yang bersangkutan. Dari keterangan di atas, penulis dapat menarik kesimpulan bahwa untuk mencapai prinsip syariah pada lembaga keuangan maka hal-hal yang harus dilakukan adalah memenuhi atau mengikuti aturan serta ketentuan-ketentuan yang dikeluarkan oleh Fatwa DSN dalam hal ini produk deposito yang ada pada Bank Muamalat Indonesia Cabang Palu telah memenuhi ketentuan-ketentuan yang terdapat dalam Fatwa Dewan Syariah Nasional Nomor 03/DSN-MUI/IV/2000 Tentang Deposito.

\section{KESIMPULAN}

Produk deposito di Bank Muamalat Indonesia cabang Palu atau yang biasa disebut BMI cabang Palu menggunakan akad Mudharabah Mutlaqah, dimana BMI diberi kebebasan dalam pengelolaan dana nasabah. Kemudian nasabah diberikan pilihan jangka waktu memproduktifkan dana tersebut. Adapun jangka waktu deposito bervariasi mulai dari jangka waktu 1, 3, 4, 6, hingga 12 bulan. Dalam pengalokasian dana deposito di BMI cabang Palu terbagi menjadi 2 kategori yaitu: individu dan nonindividu.

Ditinjau pada aturan Fatwa Dewan Syari'ah Nasional Majlis Ulama Indonesia Nomor. 03/DSN-MUI/IV/2000 Menetapkan bahwa deposito yang dibenarkan adalah 
deposito mudharabah, dan dalam ketentuan umum pada fatwa tersebut memiliki 6 poin yang harus dilaksanakan untuk tercapainya prinsip syariah oleh perbankan syariah. Dalam implementasinya produk simpanan berjangka mudharabah yang dijalankan oleh Bank Muamalat Indonesia cabang Palu telah memenuhi ketentuan-ketentuan tersebut. jadi produk simpanan berjangka mudharabah atau yang dikenal dengan tabungan deposito yang ada di Bank Muamalat Indonesia cabang Palu telah sesuai dengan fatwa tersebut.

\section{REFERENSI}

Ascarya, Akad dan Produk Bank Syariah, Jakarta: RajaGrafindo Persada, 2008

Anshori. Abdul Ghofur, Payung Hukum Perbankan Syariah (UU di Bidang Perbankan, Fatwa DSN-MUI, dan Peraturan Bank Indonesia), Yogyakarta : UII Press, 2009

Al Hadi. Abu Azam, Fikih Muamalah Kontemporer, Jakarta : PT RajaGrafindo Persada, 2017 Bank Indonesia Perbankan, Situs Bank Indonesia. Website: https://www.bi.go.id/id/peraturan/perbankan/Pages/pbi_101608.aspx

Fatwa Dewan Syariah Nasional Nomor 03/DSN-MUI/IV/2000 Tentang Deposito

Karim. Adiwarman A., Bank Islam Analisis Fiqih dan Keuangan, Jakarta : PT RajaGrafindo Persada, 2011

Mardani, Figh Ekonomi Syariah: Fiqh Muamalah, Jakarta : Kencana, 2012

Supramono. Gatot, Perbankan dan Masalah Kredit Suatu Tinjauan di Bidang Yuridis, Jakarta: Rineka Cipta, 2009

Russely Inti Dwi Permata, "Jurnal Administrasi", Analisis Pengaruh Pembiayaan Mudharabah dan Musyarakah Terhadap Tingkat Profitabilitas (Return On Equity) (Studi Pada Bank Umum Syariah yang Terdaftar di Bank Indonesia Periode 2009-2012), vol. $12 \quad$ no. 12014 ), http://administrasibisnis.studentjournal.ub.ac.id/index.php/jab/article/view/ 486 (Diakses 31 Desember 2018).

Syaakir Sofyan, “Jurnal Bilancia : Jurnal Studi Ilmu Syariah dan Hukum”, Perkembangan Perbankan Syariah di Indonesia, vol. 10 no. 2 (2016), https://doi.org/10.24239/blc.v10i2.291 (Diakses 2 Januari 2019).

Muhammad Fatibut T, "Jurnal Pendidikan Ekonomi”, Pengaruh dan Manfaat Bagi Hasil Terhadap Jumlah Simpanan Deposito Mudharabah Bank Syariah Mandiri di Indonesia, vol. 1 no. 3 (2013), http://jurnalmahasiswa.unesa.ac.id/index/php/jupe/article/view/3585 (Diakses 2 Januari 2019). 